\title{
Correction to: HACE1, GLRX5, and ELP2 gene variant cause spastic paraplegies
}

\author{
Gunes Sager $^{1}\left[\right.$ A $\cdot$ Ayberk Turkyilmaz $^{2} \cdot$ Esra Arslan Ates $^{3} \cdot$ Busra Kutlubay $^{4}$ \\ ๑) Belgian Neurological Society 2021
}

\section{Correction to: Acta Neurologica Belgica https://doi.org/10.1007/s13760-021-01649-7}

Acknowledgement Patients with FA2H gene and HACE1 gene variants were presented as a case report at the 20th Turkish National Pediatric Neurology Symposium on May 2018 (Herediter Spastik Parapleji hastalık Ailesine Olgularla Yaklaşım, Gunes Sager, Gülten Öztürk, Ayberk Türkyılmaz, Pınar Ata, Olcay Unver, Dılşad Türkdoğan P-050, ref no:313, 20th Turkish National Pediatric Neurology Symposium 2018). We gratefully thank Prof. Dr. Dilsad Türkdoğan, Ass. Prof. Dr. Olcay Ünver and Dr. Gülten Öztürk for their contributions.
Publisher's Note Springer Nature remains neutral with regard to jurisdictional claims in published maps and institutional affiliations.

The original article can be found online at https://doi.org/10.1007/ s13760-021-01649-7.

Gunes Sager

sgunessenturk@gmail.com

1 Department of Pediatric Neurology, Kartal Dr. Lutfi Kirdar City Hospital, Semsi Denizer Avenue, Cevizli, 34890 Kartal, Istanbul, Turkey

2 Department of Medical Genetics, Erzurum City Hospital, Erzurum, Turkey

3 Department of Medical Genetics, Marmara University Pendik Training and Research Hospital, Istanbul, Turkey

4 Department of Pediatric Neurology, Umraniye Training and Research Hospital, Istanbul, Turkey 